\title{
The Power of Partnership
}

Students, Staff, and Faculty Revolutionizing Higher Education

Edited by Lucy Mercer-Mapstone and Sophia Abbot 
Elon University Center for Engaged Learning

Elon, North Carolina

www.CenterforEngagedLearning.org

(2020 by Lucy Mercer-Mapstone and Sophia Abbot. This work is made available under a Creative Commons Attribution-NonCommercial-NoDerivatives 4.0 International license.

Series editors: Jessie L. Moore and Peter Felten

Copyeditor and designer: Jennie Goforth

Graphic illustrator: Sam Hester

\section{Cataloging-in-Publication Data}

Names: Mercer-Mapstone, Lucy | Abbot, Sophia

Title: The Power of Partnership: Students, Staff, and Faculty Revolutionizing Higher Education / Lucy Mercer-Mapstone and Sophia Abbot

Description: Elon, North Carolina : Elon University Center for Engaged Learning, [2020] | Series: Center for engaged learning open access book series | Includes bibliographical references and index.

Identifiers: LCCN 2019956342 | ISBN (PDF) 978-1-951414-02-3 | ISBN (pbk.) 978-1-951414-03-0 | DOI https://doi.org/10.36284/celelon.oa2

Subjects: LCSH: Teacher-student relationships | College teaching 


\section{CHAPTER 14}

\section{“I've Seen You" \\ A Conversation about the Transformative Potential of Working in Partnership}

\section{Jennifer Fraser}

University dir. of student partnership University of Westminster United Kingdom

\section{Kate Carruthers Thomas}

Senior research fellow

Birmingham City University

United Kingdom

Anna Dolidze

Undergraduate student University of Westminster

United Kingdom

\section{Rumy Begum}

Senior lecturer

University of Westminster

United Kingdom

\section{Evgeniya Macleod}

Lecturer

University of Westminster

United Kingdom

\section{Moonisah Usman}

Student partnership prog. coordinator University of Westminster

United Kingdom
Mayed Ahmed

Undergraduate student

University of Westminster

United Kingdom

\section{Fathimath Zuruwath Zareer}

Undergraduate student

University of Westminster

United Kingdom

\section{Bradley Elliott}

Lecturer

University of Westminster

United Kingdom 
bell hooks makes a powerful case for learning in partnership and the potential it contains: "Learning and talking together, we break with the notion that our experience of gaining knowledge is private, individualistic, and competitive. By choosing and fostering dialogue, we engage mutually in a learning partnership" (2010, 43). We also know from anecdotal and published evidence that partnerships can transform student and staff experiences of higher education (Cook-Sather, Bovill, and Felten 2014; Cook-Sather and Luz 2015; Healey, Flint, and Harrington 2014; Peseta et al. 2016).

But what is it about these relationships that is transformative? What factors make successful partnerships? And do partnerships need to be successful to be transformative? These are questions we are asking in a research project on the Students as Co-Creators program at the University of Westminster. Part of our method is to work collaboratively with program participants to create knowledge from within our community.

Our program team has been taking steps over the last year to ensure the program itself is co-created by participants, so everyone has a stake in the program's structures and design. For example, during the summer of 2018, we hosted a series of discussions. Some of these conversations led to the Westminster Co-Creators Principles, an iterative set of principles which outline the type of work that each group aspires toward and commits to on applying to the program. We also spent an afternoon in May with student and staff partners conversing about their experiences of the program and the processes involved in building partnerships. We captured the discussion by audio recording to enable a rich mix of voices and experiences to come through. That conversation and accompanying illustrations is the focus of this chapter.

We chose conversational methods to enact hooks' argument that dialogue can facilitate learning partnerships and applied them to a discussion about the program itself. We wanted to converse across subject positions and disciplines, to create space for reflection and to learn from each another. In the busyness of university life with its pressures to achieve grades, publish, and attend classes and meetings, we do not have many opportunities to pause and converse. This is compounded by pressures for programs to be outcome-driven with measurable impacts. We are 
attempting to push back against these pressures to consider and prioritize process, particularly the processes of relationship building that are at the heart of student-staff partnerships. To do this, we focussed on being present with one another, thinking out loud, and seeing what emerged. We wanted to foster a generative space with students and staff who were active in the program but who were not necessarily steeped in partnership literature. We hoped to center the lived experiences of partnership as a basis for generating new critical and theoretical approaches. What follows is a narrative approach to demonstrate how the conversation unfolded and how our collective thinking developed. It ends with a series of questions for readers to consider in building their partnerships or programs.

One afternoon in late May after the exam season had finished, we gathered for our conversation. We provided a brief list of guiding questions before the session, but we encouraged everyone not to prepare their answers in advance to allow a conversation to emerge. We had three students: Anna, Mayed, and Zuruwath. Anna and Mayed had each completed multiple projects, while Zuruwath had just completed her first. We also had three members of staff: Rumy, Evgeniya, and Bradley, all of whom had participated in multiple projects. Jennifer and Moonisah, who are responsible for the program, were part of the conversation as well. Finally, we were joined by Kate from Birmingham City University, who illustrated our afternoon.

As we gathered in the room with relatively comfortable furniture and warm drinks, a spectacular summer thunderstorm raged outside. The thunderstorm dramatically punctuated and sometimes paused the conversation. Nonetheless, positive energy filled the room as we listened to each other's accounts of joy, frustration, and learning in partnership.

We began by describing our experiences of the program.

Anna: In one word: “unforgettable.” As a final-year student, I'm reflecting, and I keep going back to that first project. Unforgettable because it was a really safe introduction to university life, but it also taught me a lot about employability. It was the reason I got my first job. 
Mayed: Unforgettable and exciting. I made lots of friends during the projects. It improved my writing and communication skills. In the last three years doing the projects, I met lots of academics, and they know me now. They say, "Hello." This is actually really exciting. So yeah, I'm proud.

Rumy: I like working with students quite closely. It's more relaxed. Here it's different. I came to a gathering and I met students who were in my faculty. Speaking to them about their ideas and just listening was nice. Then to work together on their idea was so nice. At first, they didn't know what the relationship was. "There's the academic. Does she tell us what to do?” But we found our way.

As the conversation warmed up, we considered the ingredients for successful partnerships.

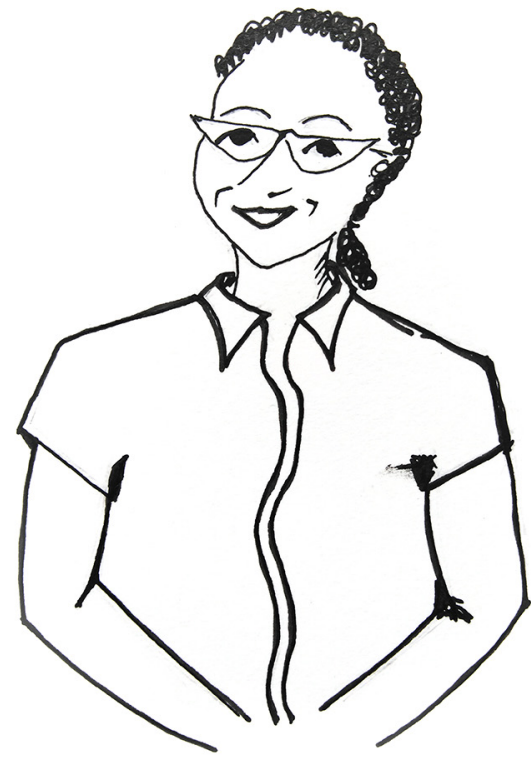

Anna Dolidze

Bradley: You need buy-in from both partners, and enthusiasm.

Rumy: You can buy in, but you also need the drive to keep it going. It comes at the busiest times, and it's an addition. You do it because you want to, but if there's no person driving it, whether it be students or staff, it won't come to fruition. Good communication is massive.

Anna: It's also about the connection between the team. For me, a successful partnership would have people that complement each other's skills and knowledge and experiences and have a mutual aim. It's really nice to see how the whole team works as one. It's like one big machine, and everyone plays an important part, and if you don't have that part, then the machine wouldn't work. 
Evgeniya: I don't think we should consider successful partnership just in terms of the project. When projects finish, that's not the end of the transformation. For example, Anna is on her third project with a different academic partner, but we still communicate very often, even without a formal framework. This kind of partnership is still going because we made a connection.

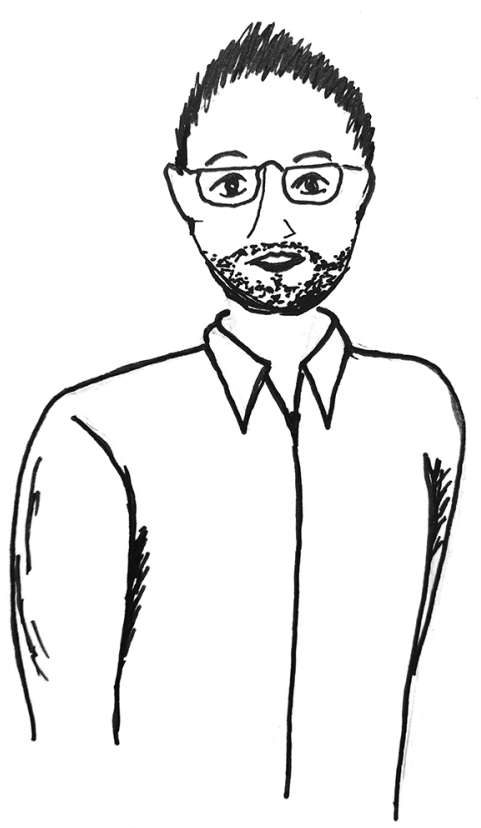

Mayed Ahmed

Mayed: You have to come to an agreement with your partner that you are both going to do this. Commitment is the main thing, and you both have to make time plans. You have to meet up to see how you are progressing. It's better when academics tell me when I'm doing something right, because that motivates us to do more.

Moonisah: If I was to think of successful partnerships as projects that finished with a decent report with some recommendations, then the successful projects were the ones where the academic and the student understood each other's commitments and communicated well.

Bradley: It's a different relationship from supervision. It needs to be a partnership, not just in name. We're supposed to be helping each other. In the first project, I had a student partner who was also my research undergraduate. I was formally in charge of a major part of her degree, and I was informally part of her making the university better. It worked. We got on really well, as a team.

Rumy: I think it's a bit of a journey. It changes with time. At different points in that journey the students might be doing more, and you might be doing more at some points, and that evolves. But your goal is the 
same: you want to complete that project in a good way so that it can lead to changes.

From here, our conversation shifted a little as we realized that we needed to develop a clearer idea of what we meant by success. We came up with a working definition: in the context of partnership projects, success means that something changes or shifts or is different at the end of the process. As we discussed what this meant, we moved to thinking through what happens in partnerships that don't meet their goals or complete their projects, or when nothing changes.

Evgeniya: In my case, it just takes longer. It's not a failure. It's this realization that a transformation that's needed might happen slowly. You need to look to long-term results, how these practices have been implemented.

Anna: Sometimes there's a danger when you're really busy, both as a student and academic, to put the project aside. If you forget why you started in the first place and what the long-term goal is, then it can be

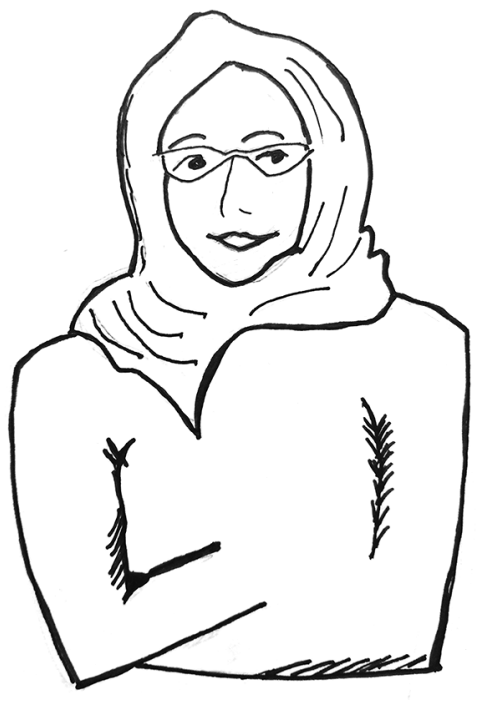

Moonisah Usman very tricky to get back on track. You need to recognize you're not alone in the team.

Moonisah: Absolutely, and there are some assumptions made. Some staff think, "If the students are not getting in touch with me, that means they're okay and they know what they're doing." But sometimes that's not the case. On the other side, students say, "Is it okay for me to keep emailing my academic partner with all these different questions?" But that's the point of partnership, you should feel comfortable in approaching them when you need to.

Rumy: I think it can be less successful if you're not drip ... drip . . drip ... drip feeding into this project. You need to have quite regular, even 
if it's little, contact. Whoever it is, that constant little "I'm here. We're doing this" is important.

We also began to unpack what we meant by success, especially in terms of thinking about who or what should change as a result of the projects.

Evgeniya: How do you define success? If I didn't affect two hundred academics in Westminster Business School, but three students transformed their lives, or me and a few friends are inspired to improve our teaching practice, is that success? If I teach and it changes a few people, over the years it will transform into more people.

Bradley: That makes sense. This is supposed to be about making things better. If you have an institutional change, then you're making things better. If you identify something could improve-and the whole point of student direction is that you know better than we do what's going wrong-and we don't make a change then that's not successful. Don't get me wrong, improved confidence, skills, and employability is great, but the aim of the project in my mind was to make Westminster a better place, and if we are not doing that

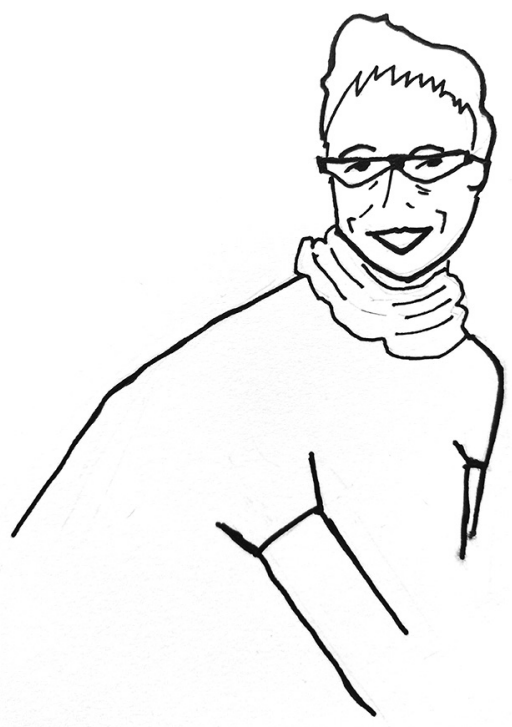

Jennifer Fraser then we're failing. It's a project that's not implementing its goal.

Jennifer: As you were all talking, I had an image of a pond with a rock that goes in the middle, and then ripples spread outwards. I think projects can be really successful for the participants but not ripple further, but that doesn't mean it's not successful. Or they can have some success in changing the way something happens locally. Others will make a change at a University level, and then people go to conferences or get on social media and actually change things outside the 
institution. Something might not change inside the institution in terms of policies or structures, but someone else takes hold of the idea and runs

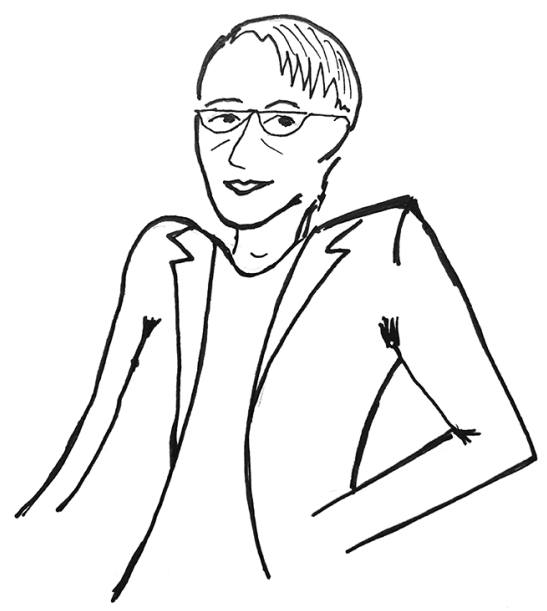

Bradley Elliott with it outside. There are different circles of change.

Bradley: Getting to see an undergraduate student do a presentation at a major conference. There were 150 people in the audience, and they quizzed her afterward. She stood there and held her own. It was really nerve-wracking because it was one of the first times in my career where I thought, "Right, that's your thing. I'm going to stand back and let you take the kudos for it because you did this." It was awesome.

In the conversation, it became clear that almost everyone had been involved in multiple projects. We were curious about what motivated this continued engagement.

Rumy: I like building relationships and finding new people to work with.

Anna: It was my first year, and I was super lost and was thinking, "Oh no, I made a mistake. I came to the UK to do my degree, and now I'm here and I have no idea what I'm doing, I have no friends." I met people, but friendships are not that easy to make unless you spend proper time together like you do as part of a partnership. And when I heard about Co-Creators, I was like, "I should totally do it." And I did. It was horrible at first because it was a very broken team, but we actually created a really nice team. I continued afterward because there were these amazing friendships, and I improved my knowledge of how the University operates.

At this point in the conversation, we shifted away from thinking about success to thinking about how working in partnership can lead to transformations in 
our learning and teaching. We began to discuss the specific types of changes that have come about through practicing learning to work in partnership.

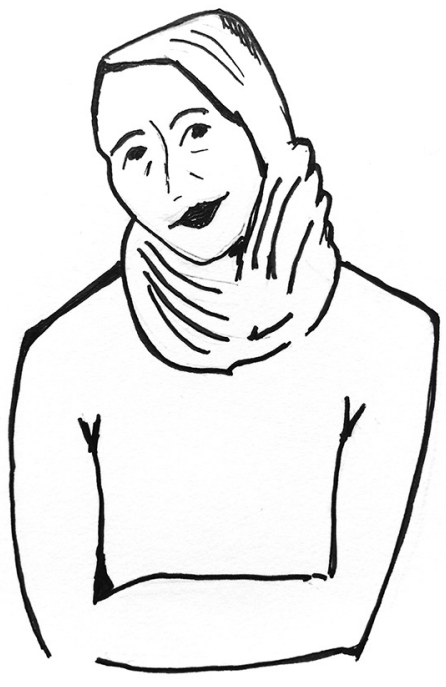

Rumy Begum
Rumy: I'm not sure if it's this or just generally, but over the last year I've been a bit more active on social media. I take part in a lot of conversations ... the Learning \& Teachings chats on Wednesday evenings. You have students and academics all giving their perspectives, and I quite like that. I think this makes me want to be more part of that and hear from different experiences, from different institutions, from different circles. It makes me more engaged with that type of social media where I can utilize these conversations in my practice as well.

Evgeniya: It's also understanding students much more after this project. I get much better feedback from students and understand how they learn, how they feel, what affects them, and that's all happening because we did that first project. Without the project, we would not have developed a relationship where I could get insight into what students think. That transformation was quite interesting.

Anna: I second that. I was in first year, and after doing the project, I knew what research was-how to conduct it, to write reports, to deliver presentations. I had this really proud moment when I was taught market research and I thought, "Oh yeah, I've done that, I've done both primary and secondary research." It made the learning experience much easier. I've really developed friendships with students and staff and gotten to know myself throughout the years: what I like, what I don't like, what I need to improve, what I'm good at. 
Bradley: I gained an understanding of the students from their point of view and how to communicate better with them. It's been a long time since I was a student. In the first year, I would give a lecture and think, "Oh my God, I told you this five times, I told you in your lecture, I wrote it in the handbook, it's on the assessments, on BlackBoard, and you can't find it." I was quite grumpy. I've learned how to communicate more effectively or in different mediums so different people get it.

Evgeniya: Even in my teaching, I tend to be moving towards partnership rather than, "I'm the teacher, the boss, I'm telling you what to read, etc. ..." It's just naturally different now.

Mayed: I feel more confident. Now I can ask any academic a question and they answer. It definitely built up my relationship skills.

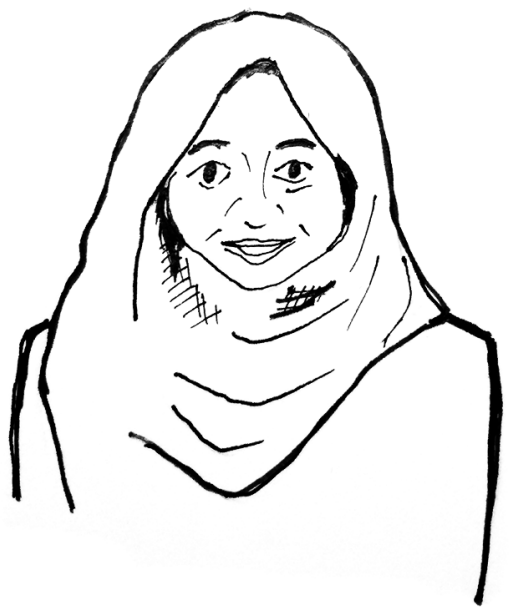

Fathimath Zuruwath Zareer

Anna: From a student perspective, when you do that type of project you inevitably break down the barriers that may exist between staff and students, because you think, "Oh, this is an academic. I shouldn't mess up in front of them or ask something silly." But when you do the partnership you realize it's just another human being and we all make mistakes, we all get super excited about something, or super sad, and we all have burning questions. You get the backstage view of what's going on in the life of an academic. So maybe you understand better why that email didn't come the next day or the same day, but it came after one week. I think it's mutual.

Zuruwath: I became more conscious of things that are happening inside the university. Before it would be things that I had identified 
as complaints, but after the project, I see these as things that can be improved.

As people shared, we began to consider what it is about the ways of working that emerge in partnership-through the structures of the Co-Creators program and the modes that groups create for themselves-that give them the possibility of being transformative.

Evgeniya: Commitment to dream-

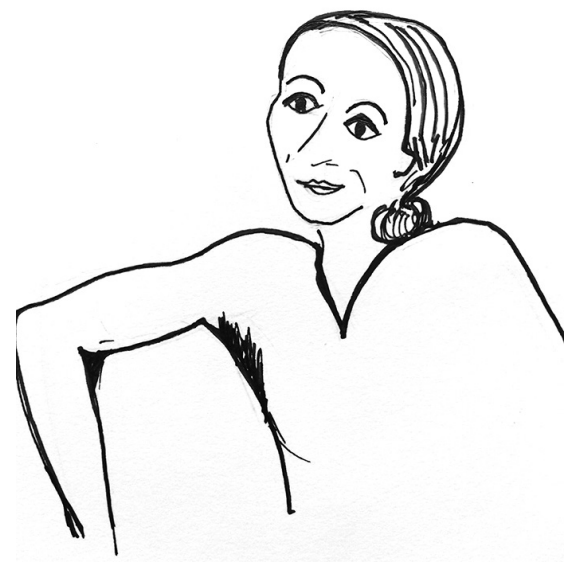

Evgeniya Macleod ing about a better world. If you get a few people together thinking and discussing what would make it better, it's inspiring, you have a dream. I think partnerships make you think, "What can we do to make it better?" There's a commitment to positive thinking because you have a project where you need to meet deadlines, and you have a friendship that continues, and you're still talking about what could make it better.

Anna: It's also about safety. From a student perspective, we have a safety net behind us to make mistakes because it's a university environment and we have an academic partner. That's very good preparation for the real world, because when you leave university and you start a job, you can make mistakes, but you will try not to because if you make a mistake, it's a big deal because you are paid for this job. Here you learn from your mistakes and then you do it better next time.

Mayed: It's teamwork and a friend relationship between the academic and the student, so it boosts your confidence to talk about your ideas and develop listening skills which are really important. You have to listen to each other to come up with a better solution. 
Rumy: In smaller groups, the transformation is more intense. You get to understand the students, the students get to understand you, and the learning is there from both perspectives. These projects are a bit research-like. When I work with students initially, I try and engage where they're at, and actually they know very little, depending on whatever stage they've come from. For me, the transformation was actually-they didn't know about little things that we take for granted. The transformation was realizing that you can't expect certain things to just happen, you need a lot of input from both angles.

Zuruwath: It's the actual work that we are doing with these partnerships that is transformative; no one comes to Uni thinking they're going to be working alongside the Uni. Everyone imagines academics to be a separate group of which they have a little knowledge. They go to them for advice, but we don't really get opportunities to be on the same level as academics, as the university, and see things from the university's perspective. There is a shift in perspective.

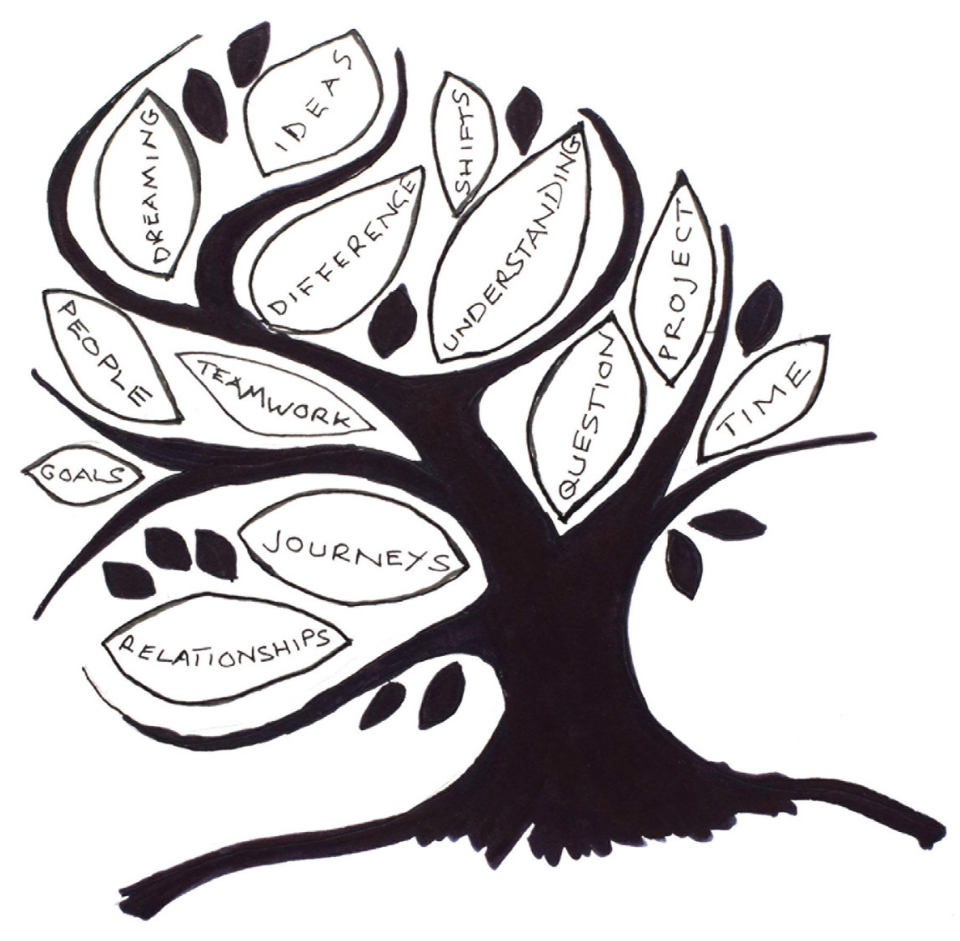


Anna: It's the sense of community and belonging, isn't it?

In the final part of our conversation, we grappled with what space the projects offer for transformation if they are not completing or making change, particularly if they are not making an institutional-level change.

Anna: Success is individual. Even the mistakes build some kind of foundations for future transformation. So next time you're doing this, whether it's this same project outside the university or your personal life, you know what not to do if you make mistakes. If everything went well, then next time you can improve. Inevitably it ends in some kind of transformation, whether or not it's instant or happens after time.

Rumy: These partnerships work not just within your own little community. I could always be stuck in science and technology, but what I find interesting is you're meeting so many individuals at so many different

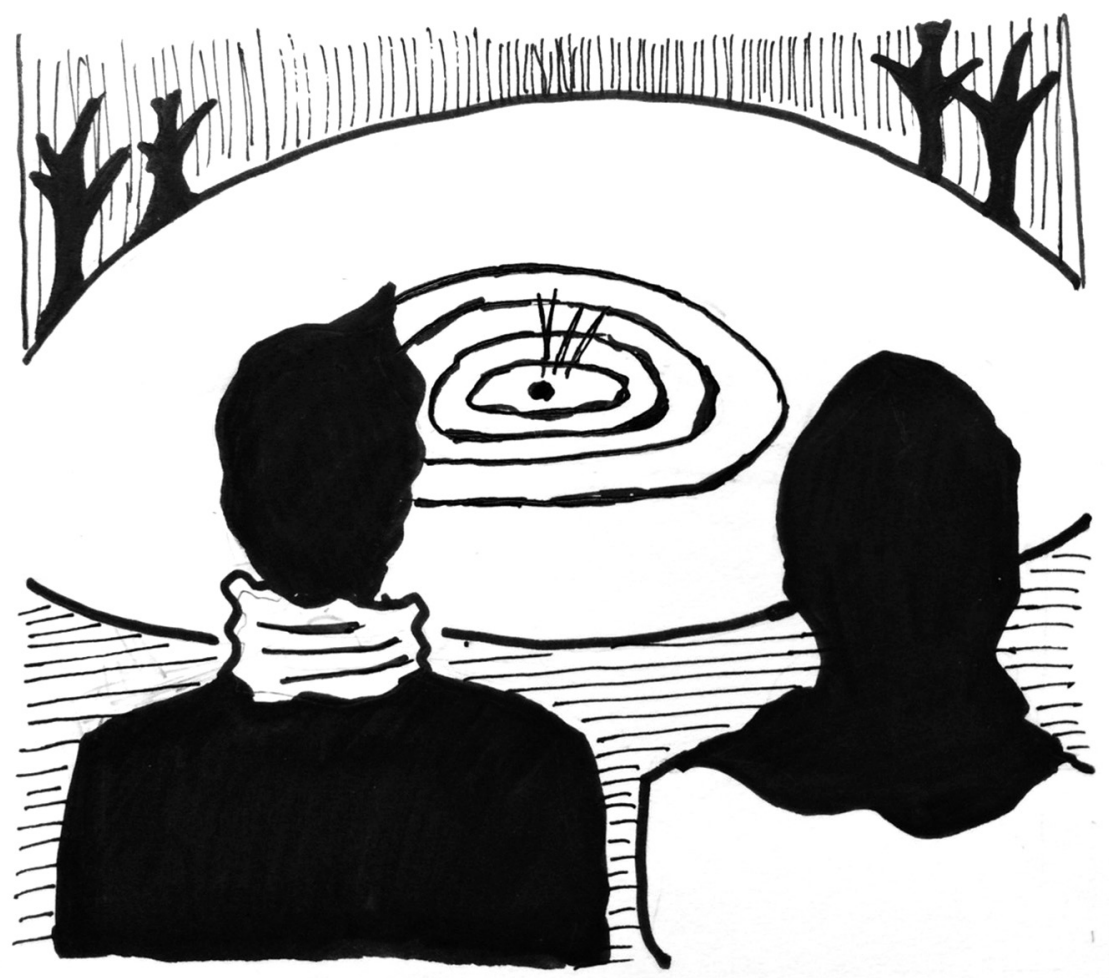


levels. It may not be beyond this room afterward, but when you see them again, it's just like, "I've seen you."

Our conversation was an opportunity to think through and surface our ideas about success and transformation in the context of student-staff partnership projects. It is not only the content but also the method we used that we think is helpful for others in considering their programs or partnerships, whether it be to create new ones or develop existing ones. Ultimately, it was, as Rumy suggested, an opportunity to see one another and engage with one another differently and thus to enrich our collective understandings of partnership.

\section{Reflection Questions for Readers}

- What does success mean to the members of your partnerships?

- What methods can you use to foster discussion about success before, during, and after partnerships?

- How is it possible to make space for an emphasis on process over product in your partnerships?

- What methods can you use to ensure that program participants have a stake in the program itself and not just in their individual partnerships?

\section{References}

Cook-Sather, Alison, Catherine Bovill, and Peter Felten. 2014. Engaging Students as Partners in Learning and Teaching: A Guide for Faculty. San Francisco, CA: Jossey-Bass.

Cook-Sather, Alison, and Alia Luz. 2015. "Greater Engagement in and Responsibility for Learning: What Happens When Students Cross the Threshold of Student-Faculty Partnership." Higher Education Research \& Development 34 (6): 1097-109. https://doi.org/10.1080/07294360 .2014.911263.

Healey, Mick, Abbi Flint, and Kathy Harrington. 2014. Engagement through Partnership: Students as Partners in Learning and Teaching in Higher Education. York, UK: Higher Education Academy. https:// 
www.advance-he.ac.uk/knowledge-hub/engagement-throughpartnership-students-partners-learning-and-teaching-higher.

hooks, bell. 2010. Teaching Critical Thinking: Practical Wisdom. London, UK: Routledge.

Peseta, Tai, Amani Bell, Amanda Clifford, Annette English, Jananie Janarthana, Chelsea Jones, Matthew Teal, and Jessica Zhang. 2016. "Students as Ambassadors and Researchers of Assessment Renewal: Puzzling Over the Practices of University and Academic Life." International Journal for Academic Development 21 (1): 54-66. https:// doi.org/10.1080/1360144X.2015.1115406. 